\title{
The Belt and Road Initiative: Research on Top Notch Innovative Talents Training in Western Universities
}

\author{
Yingli Pan \\ Ideological and Political Department Xi'an Peihua University \\ Xi 'an, shaanxi province \\ 79255432@qq.com
}

Keywords: One belt and one road; Western universities; Top-notch innovative talents; Training

\begin{abstract}
Aiming at the cultivation of top-notch innovative talents under the background of "one belt and one road", this paper analyzes the whole process of cultivating the concept, mode and method of top-notch innovative talents in the international perspective, and points out that top-notch talents should receive the orientation of higher education ability from the international perspective and train new ideas.
\end{abstract}

\section{Introduction}

The strategy of "one belt along the way" is the abbreviation for the construction of the "Silk Road Economic Belt" and the "twenty-first Century Maritime Silk Road" strategy. It is the inheritance and development of the ancient Silk Road and the maritime Silk Road, and is an important strategic plan for this administration. The implementation of the strategy of "one belt and one road" depends not only on hard power, but also on soft power. Hard power includes economic strength, political strength, diplomatic strength and military strength; the most important factor in soft power is talent. Because talent is an essential prerequisite for developing the economy, without the top-notch innovative talents adapting to the international environment, it is difficult to crack the door of other countries' markets and grasp the right to speak in the "one belt and one way" strategy. This means that the "one belt and one way" strategy poses a new challenge to the cultivation of top-notch innovative talents in western universities.

With the rapid development of science and technology in the 21 st century, the globalization of knowledge economy has become an inevitable trend. Whoever has mastered the core knowledge and creatively transformed it into productive forces can make great progress. The mastery of core knowledge is inseparable from top-notch talents from all walks of life. The development of knowledge-based economy and society in the information ecology needs a large number of talents, especially top-notch innovative talents. As the largest developing country, if China wants to get a greater degree of development, and to be in an advantageous position in the competition of comprehensive national strength, it requires all levels of education, especially higher education, to cultivate top-notch innovative talents with information literacy to meet the needs of social development. The Outline Year of the National Medium and Long-term Education Reform and Development Program emphasizes improving the quality of personnel training, renewing the concept of personnel training, innovating the mode of personnel training, and strengthening the process of education informatization.

\section{Research Content}

Understanding the influence of the "one belt and one way" national strategy background on the cultivation of top-notch innovative talents in Colleges and universities can not be trained by the "Single Soldier Combat" method in the past departments. Instead, we should regard the cultivation of top-notch innovative talents as a complex systematic project, and use the "system thinking" and "Information Ecology Thinking" to innovate the western universities. The top-notch talent training mode, integrating the interests of all parties, improving the system and mechanism, and innovating 
university governance, will improve the quality of top-notch innovative talents training in western universities, so as to meet the new needs of talents in the "one belt and one way" strategy. It is hoped that this will help to develop a new train of thought for the cultivation of cross-cultural talents in Shaanxi universities.

First, the analysis of the cultivation of top-notch innovative talents in Western Universities

The cultivation of top-notch talents should be trained in accordance with international standards. The so-called international perspective, first of all, should have the ability to accept computer science and technology from an international perspective, and then be able to stand on the same starting line with international counterparts, with the same standards to examine the development trend of disciplines, with the ability to engage in pioneering and innovative research in this discipline. The orientation of this training standard is relatively high, which requires students to develop internationalization in an all-round way, and to integrate internationalization elements into different horizontal and vertical levels of knowledge. For example, the horizontal level of human, social, aesthetic, computer science, computer ethics and other aspects of knowledge, all levels from the beginning to the end of the training link throughout the international concept; vertical such as artificial intelligence knowledge points, it is associated with anthropology, sociology, in-depth learning, ethics and other knowledge are related to the knowledge These points of knowledge come from many fields and regions, and their study needs to go through the history of human civilization.

There are three characteristics in the talent structure of Western universities: the rapid growth of the total number of talents, the continuous enhancement of talent competitiveness, and the continuous improvement of talent quality.

Table 1 Structure of social work personnel

\begin{tabular}{|c|c|c|c|c|c|c|}
\hline \multirow{2}{*}{$\begin{array}{c}\text { Total } \\
\text { number of } \\
\text { Talents }\end{array}$} & $\begin{array}{c}\text { Under 35 } \\
\text { Years of } \\
\text { Age }\end{array}$ & $\begin{array}{c}36-54 \\
\text { Years Old }\end{array}$ & $\begin{array}{c}\text { Over 55 } \\
\text { Years of } \\
\text { Age }\end{array}$ & $\begin{array}{c}\text { Intermedi } \\
\text { ate or } \\
\text { Above } \\
\text { Titles }\end{array}$ & $\begin{array}{c}\text { Primary } \\
\text { Technical } \\
\text { Job Title }\end{array}$ & $\begin{array}{c}\text { Staff } \\
\text { without } \\
\text { Title }\end{array}$ \\
\hline 4331 & 1630 & 2540 & 161 & 3510 & 243 & 578 \\
\hline
\end{tabular}

Second, "one belt and one road" strategic top-notch innovative talents training path The internationalization training of top-notch talents is different from the international vision training of ordinary undergraduates. It is mainly based on norms and incentives, and requires high standards. Specifications require internationalization, the selection of students with international training prospects, the equipping of international vision teachers, learning from the training model of international famous schools, creating a strong international atmosphere, innovating the system suitable for international vision training model, providing international conditions to support the establishment of long-term and stable international cooperation.

Third, In terms of training mode, according to the training goal of top students in international competitive disciplines, the teaching mode of international famous schools should be integrated, courses should be integrated, credits should be compressed, classical textbooks at home and abroad should be used, classes should be taught in small classes, double tutors should be provided for both academic and life, and one-to-one introductory tutors for scientific research should be provided after the second grade. The lectures of famous teachers at home and abroad are normalized, promoting learning by competition, and encouraging foreign countries to visit foreign countries in the short term. 
Table 2 Structure Of Highly Skilled Personnel

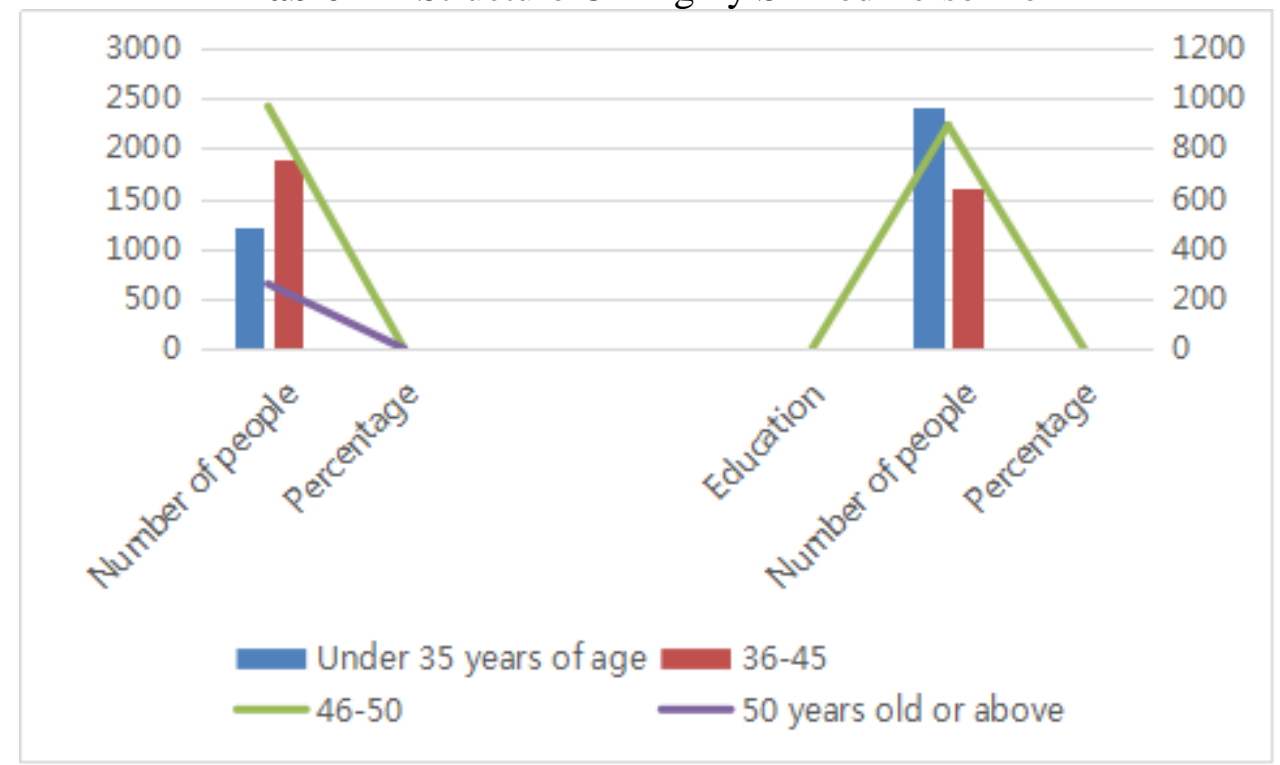

The pulse of the new economy is the opportunity to drive the new economy to take off. The core content is cloud computing, big data, artificial intelligence, Internet of things and Internet + . Undoubtedly, computer science has become the leading role, and several core contents have broken through national boundaries and touched every corner of the world. Top talent is the tide of the international wave, and should be on the stage of the world. Students should be trained to take on a sense of mission, so that they can break through international barriers with knowledge and integrate into the family of science and technology in the world.

Finally, active students join the international teaching class. Teachers with good teaching effect, high academic attainment, international learning experience, and close international exchanges will form a teaching team. Referring to the experience of MIT, Stanford, UC Berkeley and other international famous universities in computer related specialties, the training program is formulated. Reform the teaching system and build two systems: hardware system and software system. The textbooks are selected from internationally renowned textbooks. Some of them are in English and some are taught in English. Employing international and domestic teachers to concentrate on the use of holidays to teach, long-term and short-term international (frontier) exchanges, diverse forms, inclined opportunities.

\section{Conclusion}

In order to have international competitiveness, universities should first have an international perspective. Universities should cultivate an international perspective from various perspectives to meet the needs of internationalization. In the concept of personnel training, the concept of internationalization is permeated with the guiding ideology of training program formulation, the concept of integration of Chinese and Western teaching materials selection, the subtle influence of teachers in class, the influence of academic reports, the indoctrination of humanistic qualities in the East and the West, and the planning of short-term foreign visits. On the law, reform the training program, revise the syllabus, integrate the curriculum system, refine management, individualize training, select excellent teachers to form teaching teams, introduce talents to participate in teaching activities, employ foreign famous teachers to concentrate on teaching, increase investment, subsidize teaching and research activities, subsidize student travel activities, culture and culture Quality internationalization education and top-notch talent training evaluation system. 


\section{Acknowledgment}

The Belt and Road Initiative: Research on Top Notch InnovativeTalents Training in Western Universities of Shaanxi Institute of Higher Education 2018 (Project number:XGH17187)

\section{Reference}

[1] J.Wen et al. Use systematic thinking to innovate the training path of "internationalization of talents along the way" in Colleges and universities. "International business - Journal of University of International Business and Economics" 2015 issue fifth.(In Chinese)

[2] J.S.Liu J. The four "IN" is the proper meaning of the whole area. [N]. Shanghai securities news, 2015-6-2

[3] R.Zhang, Z.Dong and X. Xia Innovative Exploration of Ideological and Political Education in Colleges and Universities in the Age of Big Data [J].School Party Construction and Ideological Education, 2014 (10).(In Chinese)

[4] X.T.Yuan. National strategy analysis of "one belt and one road" construction, [J]. theory monthly, 2014 (11)(In Chinese)

[5] J.Zhang Assessment of China's peripheral security situation 2015: "one belt and one road" and surrounding strategy $[\mathrm{M}]$. Beijing: Social Sciences Literature Press, 2

[6] L.Zou Political economy of China's "one belt and one way" strategy [M]. Shanghai: Shanghai people's publishing house, 2015 